\title{
Establishment of Evaluation Index System on Construction Enterprise's Circular Economy and Empirical Study
}

\author{
Lu Yi ${ }^{1, a}$, Zhigang Liu ${ }^{2, b}$ \\ ${ }^{1}$ Department of Economy and Management, Jiangxi University of Science and Technology, \\ Ganzhou, 341000, China \\ ${ }^{2}$ Department of Student Work, Jiangxi University of Science and Technology, Ganzhou, 341000, \\ China \\ aemail:yilu991@126.com, bemail:liuzhigang991@126.com
}

Keywords: Construction Enterprise; Circular Economy; Index System

\begin{abstract}
Based on the operation mode of circular economy, this paper will combine the connotation and target of circular economy in construction enterprise to construct comprehensive evaluation index system of circular economy development level. The system includes 12 indicators under 3 sub items,such as resource investment and benefit, resource recycling and resource output indicators, then it uses the analytic hierarchy process to determine index weight. Through collecting one construction enterprise's relevant data of 2014, the paper provides empirical analysis of the circular economy development level and evaluates the construction situation and development trend of circular economy.
\end{abstract}

\section{Introduction}

At present, construction enterprises must change the traditional mode of economic development to a new model following the increasingly serious problem of resources and environment. Circular economy development model is considered to be able to resolve the sharp conflict between resource environment and economic or social development for a long time. It is an effective way to realize the sustainable development of construction enterprise [1-2]. In this process, how to scientifically construct evaluation index system of circular economy become the core and the key problems to restrict the development of construction enterprises. At the same time it's a prerequisite for the construction enterprise finding out the gap and promoting the development of circular economy.

\section{Design of circular economy evaluation index in Building enterprise}

Through the comprehensive analysis of the characteristics of enterprise production operation according to combining the ideas of the analytic hierarchy process and the basic connotation of circular economy [3-5], in this paper, the design of the recycling economy evaluation index system is divided into three levels, and 12 indicators. Target layer is expressed in X; criterion layer are respectively with the $X_{1} \sim X_{3}$. Each type of criterion layer and formed several evaluation goal set index layer respectively with Xij. The concrete index system is shown in table 1 .

Determination of index weight use analytic hierarchy process (AHP). Firstly structure a judgment matrix and assignment on the basis of consulting the opinions of experts, generally using the numbers 1 to 9 and its inverse method of scale. The greater number shows that compared to two elements, the importance of the former is stronger. Then the weights are calculated for each level, finally test the judgment matrix consistency that suggesting each level and each index weight is acceptable.

According to the established evaluation index system, the criterion layer of judgment matrix and weight indicators Yi are shown in table 2.

Make a Consistency check for judgment matrix, consistency index CI= $(\lambda \max -n) /(n-1)$ $=0.009 ; \mathrm{n}=1, \ldots, 9$. Operational researcher A .L. Saat gives the value of RI [6] (only when the CR $<0.10$, think that the consistency of judgment matrix is acceptable, otherwise the judgment matrix 
should be amended), as shown in table 3 .

Table 1 Circular economy evaluation index system

\begin{tabular}{|c|c|c|}
\hline $\begin{array}{l}\text { Target } \\
\text { layer }\end{array}$ & Criterion layer & Index layer \\
\hline \multirow{12}{*}{$\mathrm{X}$} & \multirow{5}{*}{$\begin{array}{c}\text { Resources and } \\
\text { benefit indicators } X_{1}\end{array}$} & Capital preservation increment rate $\mathrm{X}_{11}$ \\
\hline & & Return on equity $\mathrm{X}_{12}$ \\
\hline & & Profit and tax amount $\mathrm{X}_{13}$ \\
\hline & & Energy consumption per unit of output value $\mathrm{X}_{14}$ \\
\hline & & Water consumption per unit of output value $\mathrm{X}_{15}$ \\
\hline & \multirow{4}{*}{$\begin{array}{c}\text { Resource recycling } \\
\text { indicators } \\
\mathrm{X}_{2}\end{array}$} & Efficiency of energy comprehensive utilization $X_{21}$ \\
\hline & & Waste-residue comprehensive utilization rate $\mathrm{X}_{22}$ \\
\hline & & Waste-water comprehensive utilization rate $\mathrm{X}_{23}$ \\
\hline & & Waste-gas disposal rate $\mathrm{X}_{24}$ \\
\hline & \multirow{3}{*}{$\begin{array}{l}\text { Resource output } \\
\text { indicators } X_{3}\end{array}$} & Waste-residue emission reduction rate $\mathrm{X}_{31}$ \\
\hline & & Waste-water emission reduction rate $\mathrm{X}_{32}$ \\
\hline & & Waste-gas emissions reduced rate $\mathrm{X}_{33}$ \\
\hline
\end{tabular}

Table 2 Rule layer judgment matrix

\begin{tabular}{|l|l|l|l|l|l|}
\hline $\mathrm{X}$ & $\mathrm{X}_{1}$ & $\mathrm{X}_{2}$ & $\mathrm{X}_{3}$ & $\mathrm{Yi}$ & $\lambda \max$ \\
\hline $\mathrm{X}_{1}$ & 1 & $1 / 4$ & $1 / 3$ & 0.123 & 3.018 \\
\hline $\mathrm{X}_{2}$ & 4 & 1 & 2 & 0.557 & \\
\hline $\mathrm{X}_{3}$ & 3 & $1 / 2$ & 1 & 0.32 & \\
\hline
\end{tabular}

Table 3 RI mean random consistency index

\begin{tabular}{|c|c|c|c|c|c|c|c|c|c|}
\hline $\mathrm{n}$ & 1 & 2 & 3 & 4 & 5 & 6 & 7 & 8 & 9 \\
\hline $\mathrm{RI}$ & 0 & 0 & 0.58 & 0.90 & 1.12 & 1.24 & 1.32 & 1.41 & 1.45 \\
\hline
\end{tabular}

Consistency ratio $\mathrm{CR}=\mathrm{CI} / \mathrm{RI}=0.016<0.1$, as a result, the level of the judgment matrix sequencing results meet the consistency check. Similarly the judgment matrix can be calculated index layer and index weight $\mathrm{Zij}$. These are shown in table 4, 5, and 6.

Table 4 X1 Index layer judgment matrix CI=0.043;CR=0.038<0.1

\begin{tabular}{|c|c|c|c|c|c|c|c|}
\hline $\mathrm{X}_{1}$ & $\mathrm{X}_{11}$ & $\mathrm{X}_{12}$ & $\mathrm{X}_{13}$ & $\mathrm{X}_{14}$ & $\mathrm{X}_{15}$ & $\mathrm{Z} 1 \mathrm{j}$ & $\lambda$ max \\
\hline $\mathrm{X}_{11}$ & 1 & 2 & $1 / 2$ & 2 & 6 & 0.254 & 5.171 \\
\hline $\mathrm{X}_{12}$ & $1 / 2$ & 1 & $1 / 2$ & 3 & 6 & 0.216 & \\
\hline $\mathrm{X}_{13}$ & 2 & 2 & 1 & 3 & 7 & 0.373 & \\
\hline $\mathrm{X}_{14}$ & $1 / 2$ & $1 / 3$ & $1 / 3$ & 1 & 4 & 0.118 & \\
\hline $\mathrm{X}_{15}$ & $1 / 6$ & $1 / 6$ & $1 / 7$ & $1 / 4$ & 1 & 0.039 & \\
\hline
\end{tabular}

Table 5 X2 Index layer judgment matrix $\quad \mathrm{CI}=0.075 ; \mathrm{CR}=0.083<0.1$

\begin{tabular}{|l|l|l|l|l|l|l|}
\hline $\mathrm{X}_{2}$ & $\mathrm{X}_{21}$ & $\mathrm{X}_{22}$ & $\mathrm{X}_{23}$ & $\mathrm{X}_{24}$ & $\mathrm{Z} 2 \mathrm{j}$ & $\lambda \max$ \\
\hline $\mathrm{X}_{21}$ & 1 & 2 & 3 & 3 & 0.422 & 4.224 \\
\hline $\mathrm{X}_{22}$ & $1 / 2$ & 1 & 3 & 5 & 0.335 & \\
\hline $\mathrm{X}_{23}$ & $1 / 3$ & $1 / 3$ & 1 & 3 & 0.158 & \\
\hline $\mathrm{X}_{24}$ & $1 / 3$ & $1 / 5$ & $1 / 3$ & 1 & 0.085 & \\
\hline
\end{tabular}

Table $6 \mathrm{X}_{3}$ Index layer judgment matrix $\quad \mathrm{CI}=0.044 ; \mathrm{CR}=0.075<0.1$

\begin{tabular}{|l|l|l|l|l|l|}
\hline$X_{3}$ & $X_{31}$ & $X_{32}$ & $X_{33}$ & $Z 3 j$ & $\lambda \max$ \\
\hline$X_{31}$ & 1 & 4 & 5 & 0.665 & 3.087 \\
\hline$X_{32}$ & $1 / 4$ & 1 & 3 & 0.231 & \\
\hline$X_{33}$ & $1 / 5$ & $1 / 3$ & 1 & 0.104 & \\
\hline
\end{tabular}




\section{Evaluation methods of circular economy development level}

According to the theory of fuzzy comprehensive evaluation, it uses the "membership" to calculate the index of circular economy development, and then evaluates the circular economy development level of construction enterprise. The steps are as follows:

i Standardized treatment of original data. The process is put the raw data into the corresponding fuzzy membership functions, then find out the fuzzy membership degree value. Assume for an evaluated object, Aij is the measured data of the first $\mathrm{j}$ index in the $\mathrm{i}^{\text {th }}$ criterion layer, minAij and maxAij are target data in enterprise . $A^{*} \mathrm{ij}$ is the standardized data after calculation as follows[7] :

Efficiency indicator

$$
\begin{aligned}
A * i j & =\frac{A i j-\min A i j}{\max A i j-\min A i j} \\
A^{*} i j & =\frac{\max A i j-A i j}{\max A i j-\min A i j}
\end{aligned}
$$

ii According to the index layer and the weighing values for assessment index of membership degree, calculate the evaluation index of criterion layer. Formula is as follows:

$$
\begin{aligned}
& B i=\sum Z i j \times A * i j \\
& \mathrm{Z} \text { ij-Weights of indicators } \\
& \mathrm{A} * \mathrm{ij} \text { - The actual data of membership value; } \\
& \mathrm{n} \text { - Each index contains index number. }
\end{aligned}
$$

iii According to the principles of target layer weights and rule layer of evaluation index, it can calculate the index of target layer ,so the result is the circular economy development level index. Formula is as follows:

$C=\sum B i \times Y i$

Yi-- Weights of Criterion layer index.

iv According to the index, the size of the comment on it. When the index is less than 0.5 , it is the weak circulation; When the index is from 0.5 to 0.8 , it is the moderate circulation; When the index is greater than 0.8 , it is the strong circulation.

\section{Empirical studies}

The indexes of this study are based on the original data from a construction enterprise provided the related data in 2015, and individual index value is based on statistical data to calculate. Based on the data, at the same time reference to the national standard and the phased target data in the development of circular economy put forward by construction enterprises, it quantifies the actual data of membership degree according to the fuzzy membership degree of quantitative method, then use the above formula to calculate the circular economy development level of the enterprise comprehensive index, such as table 7.

From table, it shows that the composite index of enterprise circular economy development level in 2014 was 0.489 , so enterprise of circular economy was in a state of weak cycle. It also can be seen that the enterprise's score on the economic benefit and resource input, resources output are not high from data calculation results. Although obtaining the technical ability of circular economy, the enterprise has not converted the ability into economic benefit. So the enterprise needs to adjust immediately to achieve the healthy and sustainable development.

\section{Conclusion}

Through the example analysis, the evaluation index system of circular economy can scientifically evaluate circular economy development level of building construction enterprises .It will guide enterprises to implement targeted measures and further the production process of 
concrete production technical renovation, thus enterprises will accelerate the transformation of the pattern of economic development and improve the quality of the development of enterprises and economic benefits [8].

Table 7 Comprehensive evaluation of circular economy development level

\begin{tabular}{|c|c|c|c|c|c|}
\hline Index layer & $A * i j$ & Zij & $\mathrm{Bi}$ & $\mathrm{Yi}$ & $\mathrm{C}$ \\
\hline $\begin{array}{c}\text { Capital preservation increment } \\
\text { rate } X_{11}\end{array}$ & 0.17 & 0.254 & \multirow{5}{*}{0.267} & \multirow{5}{*}{0.123} & \multirow{12}{*}{$0.48 s$} \\
\hline Return on equity $\mathrm{X}_{12}$ & 0.21 & 0.216 & & & \\
\hline Profit and tax amount $\mathrm{X}_{13}$ & 0.16 & 0.373 & & & \\
\hline $\begin{array}{l}\text { Energy consumption of per unit } \\
\text { output value } \mathrm{X}_{14}\end{array}$ & 0.74 & 0.118 & & & \\
\hline $\begin{array}{l}\text { Water consumption per unit of } \\
\text { output value } \mathrm{X}_{15}\end{array}$ & 0.81 & 0.039 & & & \\
\hline $\begin{array}{c}\text { Efficiency of energy } \\
\text { comprehensive utilization } X_{21}\end{array}$ & 0.19 & 0.422 & \multirow{4}{*}{0.618} & \multirow{4}{*}{0.557} & \\
\hline $\begin{array}{l}\text { Waste-residue comprehensive } \\
\text { utilization rate } \mathrm{X}_{22}\end{array}$ & 0.88 & 0.335 & & & \\
\hline $\begin{array}{l}\text { Waste-water comprehensive } \\
\text { utilization rate } X_{23}\end{array}$ & 1 & 0.158 & & & \\
\hline Waste-gas disposal rate $\mathrm{X}_{24}$ & 1 & 0.085 & & & \\
\hline $\begin{array}{l}\text { Waste-residue emission } \\
\text { reduction rate } X_{31}\end{array}$ & 0.33 & 0.665 & \multirow{3}{*}{0.351} & \multirow{3}{*}{0.32} & \\
\hline $\begin{array}{c}\text { Waste-water emission reduction } \\
\text { rate } X_{32}\end{array}$ & 0.56 & 0.231 & & & \\
\hline $\begin{array}{c}\text { Waste-gas emissions reduced } \\
\text { rate } X_{33}\end{array}$ & 0.02 & 0.104 & & & \\
\hline
\end{tabular}

\section{References}

[1] Highfill J,McAsey M. An application of optimal control to the economics of recycling [J]. SIAM Review,2001,43 ( 4 ) :124-126.

[2] Sustainable development strategy research group of Chinese academy of sciences. 2004 Chinese sustainable development strategy report [M]. Beijing, science press, 2004:121-152.

[3] Zou An-quan,Liu Zhi-xue,Liu Ying,Xiong Zhi-yuan and so on . Design \& Evaluation of Logistics Process Reengineering in Steel Enterprises [ J].Logistics Technology, 2006(9):76 -78.

[4] ZHang Ling ying - The Comprehensive Evaluation on City's Sustainable Development [ J] . Mathematics In Practice and Theory, 2003 (7) 33:30 -35.

[5] Qu Futian. Evaluation of sustainable development: some theoretical approaches [J].China Population, Resources and Environment,1997, 7(1):50 -53.

[6] Chen Yong, Tong Zuo-feng, Pu Yong-jian . Construction and Application of the Evaluation Index System about the Circular Economy Development Level of Iron and Steel Enterprises [J]. China Soft Science, 2009(12):105-110.

[7] ZHang Rui, Ding Ri-jia, Li Hong-xin. The study of assessment index system and method on mining area’s circular economy [J]. China Mining Magazine,2009(18)11:42-44.

[8] Chen Xiaohong,Fu Taotao,Cao Yu. Evaluating system of enterprise cyclic economy: A case study of a large smelter enterprise [ J] ,Science Research Management 2012(1) :47-55. 